\title{
A Garantia do Direito Humano ao Acesso à Justiça pelo Direito Internacional
}

\section{Tatiana de A. F. R. Cardoso Squeff}

Doutoranda em Direito Internacional pela UFRGS (2014). Mestre em Direito Público pela Unisinos (2012). Pós-graduada em Relações Internacionais pela UFRGS (2015), em Direito Internacional pela UFRGS (2009) e em Língua Inglesa pela Unilasalle (2008). Professora de Direito Internacional e Relações Internacionais da Graduação em Direito do UniRitter e Unifin. tatiafrcardoso@gmail.com

\section{Laís Gorski}

Mestranda em Direito - Unilasalle/RS (2017). Pós-graduada em Direito Penal e Política Criminal: Sistema Constitucional e Direitos Humanos - UFRGS (2015). Advogada. laisgorski@yahoo.com

\section{Resumo}

Este artigo examina 0 acesso à Justiça como sendo um direito humano, assegurado constitucionalmente no âmbito doméstico, bem como em diversos tratados e convenções no âmbito internacional - documentos estes que geram obrigações para o Estado brasileiro. Mesmo com essas previsões, entretanto, constata-se recorrentemente a violação de tais direitos por parte do Estado, o que infringe diretamente o princípio da dignidade da pessoa humana - princípio fundante do Estado Democrático de Direito brasileiro. 0 presente texto, portanto, tem como objetivo discutir esse cenário. No que respeita ao acesso à Justiça e os direitos humanos analisa-se, portanto, as divergências, desdobramentos e aplicabilidade, como também se faz uma análise jurisprudencial, apontando particularidades identificadas em casos concretos submetidos ao Sistema Interamericano de Direitos Humanos diante do Estado brasileiro. Com isso, também objetiva-se mostrar a relevância da Corte Interamericana de Direitos Humanos na promoção do direito humano de acesso à Justiça - direito esse previsto na própria Convenção Americana de Direitos Humanos, ratificada pelo Brasil em 1992. Finalmente, por 
meio da análise de sua jurisprudência, revela-se os mecanismos utilizados pela Corte para realizar a efetivação destes direitos, assim como as sanções impostas, as quais geram implicações para 0 Estado brasileiro ao violar o direito humano de acesso à Justiça.

Palavras-chave: Direitos humanos. Acesso à Justiça. Corte Interamericana de Direitos Humanos. Damião Ximenes Lopes.

\title{
Safeguarding the Human Right to Access Justice Under International Law
}

\begin{abstract}
This article examines the access to justice as a human right, as it is constitutionally prescribed and is present in various treaties and conventions at the international level, creating obligations to the Brazilian state. However, even with these prescriptions, this right is recurrently infringed by the state, directly violating the principle of human dignity - the founding rule of the democratic state of Brazil. Therefore, this text intends to discuss this scenario, especially regarding the access to justice and human rights, the differences, developments and applicability are analyzed. Additionally, a jurisprudential analysis will be made so as to identify some characteristics of such right in cases submitted to the Inter-American Human Rights in the face of the Brazilian State. By doing do, this article also aims to show the relevance of the Inter-American Court of Human Rights in promoting the human right of accessing justice, especially because the American Convention on Human Rights was ratified by Brazil in 1992. After all, by analyzing such jurisprudence, it the mechanisms used by the Court to the fulfillment of these rights will be demonstrated. Moreover, the penalties imposed are also going to be exposed, as they create implications for Brazil when it violates the human right of access to justice.
\end{abstract}

Keywords: Human rights. Access to Justice. Inter-American Court of Human Rights. Damião Ximenes-Lopes.

Recebido em: 24/9/2015

Revisões requeridas em: 13/6/2016

Aceito em: 8/6/2016

\section{Sumário}

1 Introdução. 20 Acesso à Justiça como Direito Humano e os Mecanismos Disponíveis para Efetivá-lo. 2.1 A Evolução do Acesso à Justiça e seu Conceito. 2.2 0 Direito Humano de Acessar a Justiça e a Responsabilidade Internacional do Estado. 3 A Efetivação do Direito Humano de Acesso à Justiça por Intermédio do Plano Interamericano. 3.1 A Corte Interamericana de Direitos Humanos e o Direito ao Acesso à Justiça. 3.2 0 Caso Ximenes Lopes vs. Brasil e a Primeira Condenação Brasileira no Nível Interamericano. 4 Considerações Finais. 5 Referências. 


\section{INTRODUÇÃO}

O processo civil, sem vícios, é o maior garantidor da efetivação dos direitos humanos, haja vista que se trata de instrumento legal por meio do qual é permitido o acesso ao direito material subjetivo de cada pessoa, incluindo, entre estes, os direitos humanos. Ou seja, é pelo alcance da jurisdição que o indivíduo faz valer seus direitos. Direitos esses que, infelizmente, são recorrentemente violados pelo Brasil quando observada a demora do Estado na prestação jurisdicional.

Buscar-se-á, portanto, analisar o acesso à Justiça como um direito humano, reconhecido tanto no que respeita ao direito doméstico, como ao direito internacional. Afinal, o acesso à Justiça leva em conta não somente como o poder de peticionar para que a lide seja analisada por um magistrado, mas sim como um direito humano de ter um processo justo, eficaz e dentro de um prazo razoável, haja vista que a cidadania só se concretiza mediante a participação plena do cidadão, que pode ser alcançada pelo acesso às jurisdições estatais.

Fugindo, no entanto, de uma análise centrada no plano doméstico, trabalhar-se-á com o acesso à Justiça no plano internacional, eis que se poderia demandar perante a Corte Interamericana de Direitos Humanos quando da violação do acesso à Justiça por parte do Estado brasileiro, em busca da tutela efetiva deste direito humano. Nesse viés, buscar-se-á expor o primeiro caso em que o Brasil foi condenado na Corte Interamericana de Direitos Humanos, o qual envolve justamente a violação do acesso à Justiça, cujo teor, para os fins deste artigo, é justamente o pleno acesso à jurisdição do Estado, de forma justa e equitativa.

Para a realização desta pesquisa será adotada a metodologia dogmática-instrumental, realizada com base em estudos de casos da Corte Interamericana de Direitos Humanos e da revisão bibliográfica (qualitativa) sobre o tema. Por isso, trata-se de um estudo descritivo. Cumpre 
esclarecer, entretanto, que não se busca com a presente pesquisa esgotar o tema em discussão, tampouco olvidar dos demais direitos humanos frequentemente violados pelo Brasil. Apenas realizar-se-á um recorte quanto ao objeto da pesquisa, de modo que o texto se volte à análise do acesso jurisdicional, o qual não é garantido plenamente pelo Brasil, como se demonstrará a partir da própria jurisprudência do Sistema Interamericano.

Nesse sentido, o objetivo central do texto é apresentar o que seria a justa prestação jurisdicional e percepção de que esta é um direito humano, instigando o leitor a questionar por que o Brasil, um Estado Democrático de Direito, com vasta multiplicidade cultural, mas também gritantes desigualdades, não garante ao cidadão o efetivo acesso à Justiça no seu plano jurisdicional. Ademais, uma vez que o Estado falha em um de seus deveres primários, no presente artigo volta-se ao estudo do nível interamericano de proteção de direitos humanos e o seu papel na proteção do direito humano de acessar à Justiça diante da violação estatal. Afinal, esse é um instrumento que, se mais bem utilizado, poderia superar as carências sociais e garantir maior igualdade à população.

\section{O ACESSO À JUSTIÇA COMO DIREITO HUMANO E OS MECANISMOS DISPONÍVEIS PARA EFETIVÁ-LO}

Uma questão que está sempre em voga é a que trata acerca da existência de valores inerentes ao homem. São as chamadas invariantes axiológicas, isto é, os valores que determinam a essência do dever-ser humano e, até mesmo, as suas vocações e gostos. Miguel Reale (1991, p. 145) defende a tese das "invariantes axiológicas", segundo a qual os valores são criados pela experiência e cultura humanas, negando a existência de um reino axiológico pronto e definido universalmente, afirmando que os valores, uma vez criados pelos acontecimentos históricos, inserem-se na vida cultural de um povo, mesmo que venham a ser esquecidos. 
No tocante aos valores, têm-se entre eles os valores jurídicos - valores que são tutelados pelas normas de um dado ordenamento (MARTINS, 2008, p. 266). Paulo Cezar Santos Bezerra (2008, p. 10) explica que os chamados "valores jurídicos" demonstram a existência de uma axiologia jurídica, ou seja, a existência de uma "teoria dos valores” aplicada ao Direito. Tece o autor que

[o] valor é inerente a qualquer norma (...). A regra jurídica, como qualquer outra, dirige-se a fins e só tem sentido quando estes são considerados [os quais, no caso, são os valores sociais]. Sendo tais fins históricos, os valores que lhes correspondem sofrem, a seu turno, pressões sociais geradas pelo inconsciente e vigoroso sentimento de unidade social [apontando preceitos que devem ser inseridos na norma jurídica objetivando a sua proteção] (BEZERRA, 2008, p. 10-11).

Entende-se, portanto, que o Direito, de onde advêm os valores jurídicos e as normas que visam a regular a conduta social, está diretamente inserido na construção temporal da sociedade. Afinal, "toda sociedade obedece a uma tábua de valores”, os quais são invariavelmente atrelados “à fisionomia de uma época”, de modo que isso afeta "como [os] valores se distribuem ou se ordenam”, inclusive, na construção das normas (REALE, 1990, p. 191).

O Direito tem vários fins almejados. Entre eles, atualmente, têm-se a ordem, a segurança, a paz social e a justiça, como se extrai não só dos textos constitucionais dos variados Estados, como também de documentos internacionais mundialmente reconhecidos, como a Carta das Nações Unidas (ORGANIZAÇÃO..., 1945, preâmbulo). No que diz respeito ao último - a Justiça - tem-se que ela está diretamente ligada aos demais valores, pois não há Justiça sem ordem, segurança ou sem a busca pela paz da sociedade. 
Apesar disso, ciente de que a natureza possui conflitos em abundância - para dialogar com Thomas Hobbes (1997, p. 87-88) - é necessário que a Justiça saia do plano ideal (abstrato) e passe para o institucional (real) (BITTAR, 2001, p. 411), não sendo possível admitir que cada indivíduo proceda de acordo com os seus impulsos e desejos pessoais sem respeitar os interesses dos demais na vida em sociedade (BEZERRA, 2008, p. 50). E para evitar que os indivíduos e os grupos se “digladiem”, prejudicando a convivência em comum, a sociedade cria sistemas de regulamentação da vida social, pelos quais se estabelecem normas para a conduta de seus membros.

Em se tratando de controle social há uma ideia que é fixa: a de que tal controle "é um conjunto de meios pelo qual a sociedade trata de conseguir que seus membros se comportem de conformidade com os padrões de conduta aceitos pela coletividade" (FRANCO, 2014, p. 278). E caso as condutas oriundas do controle social sejam desobedecidas, precisa-se de uma sanção (KELSEN, 2000, p. 26-28); para tanto, faz-se necessário um meio digno de busca de justiça para a efetivação dos direitos, em que se inclui o acesso à jurisdição.

Nesta seara, tem-se o 'Acesso à Justiça' como sendo um direito humano, reconhecido tanto no âmbito interno pela Constituição de 1988, assim como no plano externo, pela Convenção Interamericana de Direitos Humano. Direito esse que pode ser classificado como um meio, um facilitador, para a solução de conflitos sociais. Apesar disso, sabe-se que o acesso à Justiça é realmente um problema no Brasil e que a falha na prestação jurisdicional afeta diretamente a efetividade dos próprios direitos humanos (GRINOVER; DINAMARCO, 2014, p. 78).

Por isso, faz-se necessário o estudo do contexto histórico e da conceptualização do direito de acesso à Justiça, bem como a sua classificação como um direito humano, de modo que se possa abordar essa questão tão importante que é a situação brasileira. 


\subsection{A Evolução do Acesso à Justiça e seu Conceito}

Antes de o homem viver em sociedade ele encontrava-se em "estado de natureza”, prevalecendo a força como forma de solução de conflitos (HOBBES, 1997, p. 21). Assim, nas versões mais primitivas da aglomeração humana, sem leis concretas e eficazes, valia-se do regime da autotutela (ou autodefesa) para dirimir quaisquer conflitos - modelo este em que prevaleceria sempre a força (TEIXEIRA, 2012, p. 103; GRINOVER, 2005. p. 21).

$\mathrm{Na}$ esteira do desenvolvimento da vida social, porém, a Justiça e sua administração apresentaram evoluções significativas. O relato mais antigo existente na humanidade acerca do acesso à Justiça está consubstanciado no Código de Hamurabi, datado em 18 a.C (MORAIS; SILVA, 1984, p. 18-19). Tal Código era embasado no aspecto religioso, em que o rei era a personificação da Justiça e tinha a incumbência de resolver as lides, de modo que era possível quaisquer cidadãos que se encontrassem em situações de desigualdade ou dificuldade, recorrer ao ao rei para ver seu problema solucionado (OLIVEIRA, 2007, p. 65).

Tratar da evolução do direito de acesso à Justiça obriga a citação da Grécia como precursora de tal garantia. Afinal, foi na Grécia que surge a ideia de isonomia, a qual está intimamente ligada ao movimento de acesso à Justiça (OLIVEIRA, 2007, p. 65), que posteriormente influenciou, também, na criação e desenvolvimento dos direitos humanos. Ressalta-se, ainda, que a Grécia foi o berço da democracia, de modo que a todo aquele considerado cidadão grego era conferido o direito de acessar a Justiça. A figura do juiz, contudo, era vista apenas como auxiliar, tendo em vista que era o povo quem decidia as lides (CAPPELLETTI; GARTH, 1988, p. 20).

Ato contínuo, em Roma havia uma preocupação com a positivação do Direito, o que terminou por influenciar os sistemas jurídicos dele decorrentes ao redor do mundo. O Direito Romano, portanto, igualmente 
contribuiu para o acesso à Justiça, vez que discutiu o Direito de uma forma justa e ética, e almejou sempre tutelar os menos favorecidos economicamente, de forma a criar um ambiente em que os governados mostrassem ter certa igualdade entre si (LIMA FILHO, 2003, p. 111).

Já o período da Idade Média foi regido pela ideologia oriunda da Igreja. O denominado "Direito Canônico" criou, assim, um ordenamento jurídico em que a doutrina do "amor ao próximo" determinava que, por exemplo, os advogados não cobrassem honorários dos necessitados e tampouco os magistrados cobrassem as custas processuais (HORTA, 2003, p. 44; OLIVEIRA, 2007, p. 65). Evidencia-se, com isso, um meio facilitador de acesso à Justiça, no qual todos tinham, ao menos, a oportunidade de buscar o acesso à jurisdição.

Em relação à Revolução Francesa, esta é tida como um importante marco para o Direito na esfera intercontinental e fundamental para a positivação do acesso à Justiça. Isso porque os nortes da mencionada Revolução - Igualdade, Fraternidade e Liberdade - trouxerem uma base fundamental para a construção dos direitos de primeira dimensão, os quais se sustentam na igualdade formal entre os homens, impondo uma limitação à atividade estatal no que tange às liberdades fundamentais dos cidadãos de modo a não frear a sua concretização, (CARDOSO, 2014, p. 37), entre os quais estava o acesso à Justiça, notadamente quanto à necessidade de organizar as instituições para viabilizar a jurisdição estatal aos que dela reivindicavam uma solução às suas contendas (OLIVEIRA, 2007, p. 65).

Até mesmo porque, nos Estados se moldavam entre os séculos 17 e 19, apesar de o acesso ao poder Judiciário ser considerado um direito natural, a Justiça estava disponível somente para os que tivessem condições econômicas de acessá-la. Por isso, além de permanecer inerte em relação à forma que o indivíduo escolheria para dirimir suas contendas, $o$ Estado devia ofertar esse mecanismo independentemente das condições socioeconômicas do agente (DUARTE NETO, 2012, p. 64). 
A igualdade material, todavia, só foi reconhecida em meados do século 20, quando os direitos sociais evoluíram significantemente, desencadeando discussões acerca do acesso à Justiça, especialmente no tocante à efetiva garantia desse direito, não mais sendo apenas uma previsão meramente positivada (COMPARATO, 1996, p. 59). O Estado passa, a partir de então, a atuar assegurando o acesso ao poder Judiciário, tendo em vista que, na esmagadora maioria dos casos, a não concessão/viabilização de acesso à Justiça está intimamente ligada à condição socioeconômica do agente.

Outrossim, foi somente entre as décadas de 50 e 60 que os movimentos de acesso à Justiça ganham força nos países americanos, notadamente na esfera constitucional, buscando maneiras de viabilizar a todos uma forma para obter soluções justas aos litígios entre os pares, especialmente pela mobilização diante da tutela dos direitos sociais (ROCHA, 2005, p. 180; CAPPELLETTI; GARTH, 1988, p. 31-49). Acerca disso, exprime Cichocki Neto (2000, p. 15):

A inscrição de garantias do acesso à justiça, nos textos constitucionais, constitui um método a torná-la efetiva para os povos, o que quer dizer que todos os sistemas jurídicos deveriam criar mecanismos justos e efetivos para que as pessoas possam não somente recorrer ao Judiciário para satisfazerem suas pretensões, mas que também possam obter um resultado moralmente justo com a disponibilidade de meios efetivos para $o$ alcance das suas pretensões.

É possível, portanto, afirmar que o acesso à Justiça evoluiu de maneira palpável através dos tempos, sempre com características do momento histórico de cada época, porém continuamente com a mesma finalidade: de proporcionar a todos o acesso ao poder Judiciário, dentro de um prazo razoável, para "fazer justiça” (no sentido de dirimir as suas divergências; de fazer valer o direito pretendido). 
Especificamente no Brasil, é importante esclarecer o direito subjetivo do cidadão juridicamente necessitado ao acesso à Justiça foi reconhecido, não surgiu apenas com o advento da Lei Federal n. 1.060/50 em alinhamento com as modificações que estavam ocorrendo mundo afora (ALVES, 2003, p. 213; OLIVEIRA, 2007, p. 70), já sendo encontrado como princípio constitucional ainda na Carta Política de 1934, em que pese a Constituição outorgada em 1937 não ter feito menção à matéria (ALVES, 2003, p. 321).

A ideia de um acesso ao sistema Judiciário, contudo, persistiu, vindo à tona na Constituição de 1946, repetindo-se na Carta de 1967, a qual acompanhava o entendimento exteriorizado à época por meio da Lei Federal n. 4.717/65 acerca da Ação Popular, e na Constituição de 1988, sedimentando modificações legislativas anteriores como a Lei Federal n. 7.244/84 acerca dos Juizados Especiais de Pequenas Causas (ALVES, 2003, p. 321).

Além disso, a Constituição de 1988 situou o acesso à Justiça como direito humano, estando prevista no artigo $5 \square$, inciso XXXV, dando a todos os brasileiros e estrangeiros residentes no Brasil a garantia do acesso ao poder Judiciário, de modo que as suas pretensões sejam solucionadas (BRASIL, 1988). Essa inserção acompanha o preâmbulo do referido diploma legal, posto que ele já revela uma profunda preocupação com as desigualdades sociais existentes em terrae brasilis, evidenciando a necessidade de banir, a partir da ordem constitucional, a tônica individualista, introduzindo uma visão mais social do direito.

Logo, parece lógico afirmar que o acesso à Justiça é uma busca inesgotável para que as demandas sociais rompam o formalismo em prol da efetivação dos direitos. Corroboram com essa afirmação Mauro Cappelletti e Bryan Garth (1988, p. 88) ao defenderem que o acesso à Justiça pode ser encarado como requisito fundamental, o mais básico dos direitos humanos, de um sistema jurídico moderno igualitário que pretenda garantir e não apenas proclamar os direitos de todos. Nas palavras dos autores, 
[a] expressão "acesso à justiça” [...] serve para determinar duas finalidades básicas do sistema jurídico - sistema pelo qual as pessoas podem reivindicar seus direitos e/ou resolver seus litígios sob os auspícios do Estado. Primeiro, o sistema deve ser igualmente acessivel a todos; segundo, ele deve produzir resultados que sejam individual e socialmente justos (CAPPELLETTI; GARTH, 1988, p. 9).

Assim, é inegável que o acesso à Justiça apresenta duas finalidades primordiais atualmente, quais sejam, que o sistema jurisdicional seja acessível e igual a todas as pessoas e que os resultados oriundos deste ingresso no sistema Judiciário sejam justos para ambas as partes litigantes. Por isso, não é mais possível afirmar que o acesso à Justiça é apenas a garantia de ingresso ao poder Judiciário, sem quaisquer preocupações com as questões sociais.

Afinal, com a evolução da sociedade, a concepção desse direito sofreu mutações, passando a adotar a visão do processo como sendo um instrumento de jurisdição, com fins sociais. $\mathrm{O}$ acesso à Justiça passou a almejar, acima de tudo, que a população pudesse cada vez mais buscar a satisfação dos seus direitos, fazendo uso do princípio basilar do devido processo legal. Concorda-se, portanto, com os referidos autores no sentido de que o acesso à Justiça engloba um conteúdo amplo, que abrange uma série de outros direitos, permitindo a efetivação dos demais direitos humanos.

Tal acesso engloba, acima de tudo, o direito a ter direitos ou, como a recente doutrina denomina, de "acesso à ordem jurídica justa” (WATANABE, 2009, p. 698). Neste mesmo sentido disserta Cândido Dinamarco (2013, p. 33):

[...] o acesso à Justiça é, pois, a ideia central que converge toda a oferta constitucional e legal desses princípios e garantias. Assim, (a) oferece-se a mais ampla admissão de pessoas e causas ao processo (universalidade de jurisdição), depois (b) garante-se a todas elas (no cível e no criminal) a observância de todas as regras que consubstanciam o devido processo legal, para que (c) possam participar 
intensamente da formação do convencimento do juiz que irá julgar a causa (princípio do contraditório), podendo exigir dele a (d) efetividade de uma participação em diálogo, tudo isto com vistas a preparar uma solução que seja justa, seja capaz de eliminar todo resíduo de insatisfação. Eis a dinâmica dos princípios e garantias do processo, na sua iteração teleológica apontada para a pacificação como justiça.

Assim, tem-se que é a partir do exercício do acesso à Justiça que poderão ser assegurados e reconhecidos os demais direitos, inclusive atingindo os objetivos constitucionais da Nação, listados no artigo $3^{\circ}$ da Constituição de 1988, incisos I e III, quanto à constituição de uma sociedade justa e solidária, e à redução das desigualdades sociais (BRASIL, 1988). E em razão disso, foi inserido na Constituição de 1988 como um direito básico do homem, o qual não pode ser tratado como uma letra morta da lei, isto é, de maneira insignificante (CAPPELLETTI; GARTH, 1988, p. 18), sendo parte da dignidade humana - que é um fundamento da República Federativa do Brasil (BRASIL, 1988, art. 1, inc. III).

Com isso, entende-se necessário aprofundar o estudo do acesso à Justiça como sendo um direito humano, não positivado apenas no plano doméstico, mas também assegurado de uma maneira global. Afinal, o acesso à Justiça não é apenas uma preocupação brasileira, sendo também entendido como uma preocupação legítima da comunidade internacional, o qual exige a atenção de todos (PIOVESAN, 2013, p. 70).

\subsection{O Direito Humano de Acessar a Justiça e a Responsabilidade Internacional do Estado}

O primeiro documento internacional a reconhecer o direito de acessar a Justiça de maneira pronta e efetiva foi a Declaração Universal de Direitos Humanos de 1948, cujo artigo $10^{\circ}$ prescreve que “[t]oda pessoa tem direito, em plena igualdade, a que sua causa seja equiitativa e publica- 
mente julgada por um tribunal independente e imparcial que decida dos seus direitos e obrigações ou das razões de qualquer acusação em matéria penal que contra ela seja deduzida” (ORGANIZAÇÃO..., 1948).

Nesta mesma esteira, tem-se a Convenção Americana de Direitos Humanos (ou Pacto de San José da Costa Rica), de 1969, o qual o Brasil ratificou por meio do Decreto $\mathrm{n}^{\circ} 678$ em 1992 e que igualmente prescreve o direito à prestação jurisdicional sem dilações indevidas. Especificamente, as garantias do devido processo legal são asseguradas no artigo $8^{\circ}$, parágrafo $1^{\circ}$, da referida Convenção, redigido nos seguintes termos:

Toda pessoa terá o direito de ser ouvida, com as devidas garantias e dentro de um prazo razoável, por um juiz ou Tribunal competente, independente e imparcial, estabelecido anteriormente por lei, na apuração de qualquer acusação penal formulada contra ela, ou na determinação de seus direitos e obrigações de caráter civil, trabalhista, fiscal ou de qualquer outra natureza.

Além disso, outro artigo do mesmo diploma legal que aponta a garantia da prestação jurisdicional como sendo um mecanismo para evitar a violação de direitos humanos é o 25 , parágrafo $1^{\circ}$, , estando assim descrito:

Toda pessoa tem direito a um recurso simples e rápido ou a qualquer outro recurso efetivo, perante os juízes ou tribunais competentes, que a proteja contra atos que violem seus direitos fundamentais reconhecidos pela Constituição, pela lei ou pela presente Convenção, mesmo quando tal violação seja cometida por pessoal que estejam atuando no exercício de suas funções oficiais.

Assim, importante anotar que tais instrumentos internacionais de proteção dos direitos humanos consagram os parâmetros basilares a serem respeitados pelos Estados, devendo ser utilizados perante as instâncias internas e externas. Por isso, tem-se que os instrumentos internacionais, em conjunto com o Direito interno, aprimoram o sistema de proteção 
dos direitos humanos. Nesse viés, especificamente no Brasil, o entendimento é pacífico de que é direito de todo o cidadão ter sua demanda resolvida, no plano judicial, da maneira mais célere possível - não só pela internalização dos referidos documentos internacionais, como também pelas próprias previsões contidas na Constituição de 1988, o acesso à Justiça encontra-se assegurado.

Segundo a Carta Política de 1988, a "lei não excluirá da apreciação do poder Judiciário lesão ou ameaça a direito” (BRASIL, 1988, art. 5º inc. XXXV). Ademais, "ninguém será privado da liberdade ou de seus bens sem o devido processo legal" (BRASIL, 1988, art. 5º, inc. LIV) - direito esse que automaticamente inclui o contraditório e ampla defesa, além de todos os meios e recursos cabíveis aos litigantes (BRASIL, 1988, art. 5ㅜ, inc. LV). Além disso, a própria reforma do poder Judiciário brasileiro de 2004, a qual inseriu no texto constitucional o inciso LXXVIII ao artigo $5^{\circ}$, por meio da Emenda Constitucional n⿳o 45, menciona que ao cidadão deve ser garantido o direito à devida prestação jurisdicional em um prazo razoável (BRASIL, 2004).

Essas normativas, por conseguinte, consagram como sendo um direito humano o acesso às Cortes, bem como um julgamento imparcial por um tribunal independente, além de obter-se uma decisão proferida dentro de um tempo razoável. Direito esse que além de preservar a dignidade humana, acarreta o pleno gozo de sua cidadania, uma vez que este termo refere-se à participação de um indivíduo em uma sociedade, por meio do qual este sente-se acolhido e identificado, sendo tratado com igualdade (JAKOBSEN, 2007, p. 173).

Assim sendo, uma vez reconhecida a garantia do acesso à Justiça como um direito humano - pedra angular para a realização de outros direitos e da própria diminuição de desigualdades - é importante combater-se a demora da prestação jurisdicional. Isso porque, quando não se efetiva o acesso à Justiça de modo correto, tem-se a consequente violação de outros 
direitos. Nesse viés, é possível concluir que não é direito humano tão somente o acesso à Justiça em si, mas principalmente a tutela jurisdicional completa (DIAS, 2004, p. 108), isto é, que ela seja ofertada/possibilitada de maneira rápida - sem dilações indevidas.

Não é recente o problema da ineficácia da Justiça pátria, seja pela deficiência de seus meios, seja pela morosidade. O principal problema desencadeado desta ineficácia, contudo, é a dificuldade que a maioria das pessoas tem em acessar a Justiça, o que, do ponto de vista social, pode ser perigoso, pois fomenta na sociedade o anseio de encontrar caminhos próprios para resolver seus conflitos, os quais são incompatíveis com as regras positivadas na Lei Maior e, até mesmo, desumanas (ROSSI, 2014, p. 1).

Assim sendo, o acesso à Justiça não pode estar resumido à mera oportunidade de acessar o poder Judiciário, mas sim que o indivíduo alcance a satisfação justa e eficaz do seu direito em tempo hábil. Ao Estado cabe o dever de ressarcir os prejudicados pela ineficiente prestação jurisdicional, que pode ser oriunda da falha dos agentes judiciários ou pela falha do próprio sistema do serviço público (DIAS, 2004, p. 108).

Neste viés, Volnei Ivo Carlin (apud ANNONI, 2009, p. 7) expõe que também a inaptidão ou o despreparo do julgador constituem fatores determinantes do comprometimento da estrutura do Estado. Afinal, “[a]o mesmo tempo em que tornam a ação do órgão de controle ineficaz abalam ainda mais o restante do prestígio do derradeiro protetor do cidadão, desgastando não só sua imagem, como estremecendo um dos próprios fundamentos do Estado, tornando-o completamente inseguro" (ANNONI, 2009, p. 7-8).

Neste enfoque, os doutrinadores costumam elencar uma série de modalidades de atividades jurisdicionais danosas, como a demora na prestação jurisdicional, a chamada denegação da Justiça (SERRANO JUNIOR, 1995; THEODORO JUNIOR, 1993). Annoni (2009, p. 122) explica que a 
denegação da Justiça é gênero, do qual fazem parte a demora na prestação jurisdicional e o exercício arbitrário do poder discricionário. Constitui-se, pois, pela ausência da prestação jurisdicional, sua negação, seja de acesso, seja de pronta resposta.

Logo, nota-se que a demora na prestação jurisdicional é uma verdadeira ofensa ao direito do cidadão de aceso à Justiça de forma pronta e eficaz. Uma vez que um cidadão busca o poder Judiciário e não encontra uma resposta em um prazo considerado razoável, a sua demanda termina por não encontrar resposta alguma, configurando a denegação da Justiça e a privação de todos os demais direitos que dela poderiam ser alcançados - inclusive a própria desconsideração da cidadania.

Atualmente o processo civil é visto pelos processualistas modernos como um instrumento a serviço da paz (CINTRA; GRINOVER; DINAMARCO, 2014, p. 41). Danielle Annoni (2008, p. 6.682-6.683), neste cotejo, afirma que falar em efetividade tornou-se, pois, imprescindível, tendo os processualistas modernos passado a analisá-la como instrumento de realização da Justiça. Este ponto de vista torna-se extremamente válido quando se conclui que a maior ameaça aos direitos do ser humano reside na incapacidade do Estado em assegurar o acesso à jurisdição de maneira eficaz. Tal incapacidade, que em grande parte dos casos é injustificada, é refletida pela ausência de mecanismos de materialização dos direitos - e, por que não, dos próprios objetivos e fundamentos da nação (BRASIL, 1988 , artigos $1^{\circ}$ e $3^{\circ}$ ).

Existe, portanto, uma negação do Estado, que em tese, deveria ser constituído como Democrático e de Direito. Nesse viés, Carlos Alberto Menezes Direito (1998, p. 142) lembra que "o maior esforço que a ciência do Direito pode oferecer para assegurar os direitos humanos é voltar-se, precipuamente, para a construção de meios necessários à realização nos 
Estados e, ainda, para o fortalecimento dos modos necessários de acesso à Justiça com vistas ao melhoramento e celeridade da prestação jurisdicional”.

Para tanto, é necessário que o poder Judiciário disponha de mecanismos aptos a realizar a devida prestação jurisdicional no menor tempo possível, de maneira efetiva e com uma decisão tempestiva. É inegável que quanto mais longe da ocasião propícia for proferida a sentença, mais ilusória e sem força será a sua eficácia, bem como mais frágil e também utópico será o reconhecimento do direito em questão. $\mathrm{O}$ julgamento tardio perde, de maneira progressiva, a sua finalidade, que é a de fazer valer o direito pretendido - a "justiça” (LIMA FILHO, 2003, p. 292).

A partir disso, nota-se que a tutela jurisdicional injusta não é somente aquela eivada de vícios ou com decisões respaldadas de dolo, fraude ou culpa do julgador, mas também aquela deficiente e injusta, com demasiado atraso (TUCCI, 1997, p. 66). Noutros termos, a demora do poder Judiciário colabora com a violação, não só do direito que está se pleiteando, como também do direito humano de acesso à Justiça, bem como o direito à dignidade da pessoa humana e a cidadania do indivíduo.

O cidadão que busca o acesso à Justiça já foi uma vez lesado, sendo assim, não há que se falar em dever maior do Estado senão garantir que o jurisdicionado não seja novamente lesado, desta vez pelo próprio Estado. Nesse sentido, uma vez que o Estado tem o dever de garantir não só o acesso ao poder Judiciário, mas também a presteza na sua realização a fim de fazer valer o direito ora violado, e, consequentemente, o acesso à Justiça; quando ele não o garante, não resta ao cidadão outra alternativa para a solução do problema senão buscar uma medida efetiva em outro nível jurisdicional. Afinal, o Estado não é somente responsável por promover os direitos humanos, mas também pela sua omissão, isto é, por não tomar as medidas cabíveis de proteção ou deixar de garantir certo direito de forma plena (TRINDADE, 1991, p. 74). 
Assim sendo, se compete primariamente ao Estado assegurar os direitos humanos daqueles inseridos na sua jurisdição, uma vez violado o acesso à Justiça pela conduta estatal, não poderiam os indivíduos permanecer com seus direitos transgredidos, podendo, portanto, recorrer ao plano internacional para obter uma reparação integral do dano gerado pelo Estado (CARDOSO, 2010, p. 347). Isso porque, como explica André de Carvalho Ramos (2004, p. 107-109), existem três elementos essenciais para que a responsabilidade internacional do Estado seja estabelecida, quais sejam, ( $a$ ) a existência de uma ação ou omissão que viole uma norma de Direito Internacional, $(b)$ a imputação de tal ato ao Estado e $(c)$ a ocorrência de um dano ao lesado.

Diante do reconhecimento do acesso à Justiça como sendo um direito humano, tanto no plano internacional como na esfera constitucional brasileira, a prestação jurisdicional há de ser justa e eficaz. $\mathrm{O}$ papel do Estado - entre eles o brasileiro - é ser o zelador primário dessa regra, advogando para que o processo finde dentro de um lapso temporal razoável e com uma solução "justa” (isto é, faça valer o direito violado). Logo, privar o cidadão de acessar a Justiça suscita a responsabilidade internacional do Estado que o privou de tal direito, haja vista a violação direta por ele cometida por intermédio do seu poder Judiciário, seja por uma ação (tendo a sua própria conduta violado direito humano) ou omissão (tendo a sua inatividade causado a violação do direito humano) ter gerado um dano ao indivíduo (CARDOSO, 2010, p. 343; INTERNATIONAL..., 2001, $\operatorname{artigos} 1^{\circ}$ ao $\left.4^{\circ}\right)$.

E no que tange os direitos humanos, "a relutância dos poderes do Estado em tomar medidas positivas para dar plena vigência aos Tratados de Direitos Humanos é injustificável, e contribui à configuração de um ilícito internacional imputável ao Estado em questão” (TRINDADE, 1997, p. 437). Ademais, há uma obrigação internacional de todos os Estados em protegerem tais direitos de forma clara e eficaz, eis que essas normas são 
revestidas de caráter erga omnes (MERON, 1986, p. 9). Nesse sentido, em caso do descumprimento do postulado, não restam dúvidas de que o Estado responderá internacionalmente, de maneira subjetiva, pelo dano causado ao cidadão pela inobservância de seu direito humano.

Em razão disso, inclusive, evidencia-se que o Direito Internacional deixou de proteger apenas os interesses e reparar os danos oriundos por disputas entre Estados, passando a tutelar o indivíduo como sujeito de Direito. Como observa Patrícia Galvão Ferreira (2001, p. 24), “a natureza objetiva das obrigações de proteção de direitos humanos consagra o indivíduo como principal preocupação da responsabilidade internacional do Estado por violação de direitos humanos”. Logo, o Estado passa a ter de observar as obrigações por ele assumidas não só perante os demais Estados, como também em relação aos seus jurisdicionados, sob pena de ser responsabilizado internacionalmente.

Aliás, a regra de responsabilização internacional dos Estados tem como objetivo a reparação dos danos havidos e tem por efeito evitar novas violações de normas internacionalmente reconhecidas, mantendo as relações seguras e pacificadas entre Estados e indivíduos (RAMOS, 2004, p. 20). Por isso, não cabe aos Estados eximir-se de responder, por seus atos e omissões, por denúncias de violações de direitos humanos de seus jurisdicionados perante órgãos de supervisão internacional (TRINDADE, 1997, p. 83) - de modo que o Brasil não é uma exceção.

Considerando, entretanto, que a inefetividade do processo configura verdadeira negação do direito de acesso à Justiça e que o Estado brasileiro recorrentemente viola essa previsão normativa, analisar-se-á na próxima seção o local em que o Brasil poderia ser acionado quando do descumprimento desse direito humano, sendo responsabilizado internacionalmente por sua conduta ilícita, utilizando-se do primeiro caso em 
que o Brasil foi responsabilizado pela negativa de acesso à Justiça, bem como o direito a um recurso jurídico dentro de um prazo razoável, para corroborar com a explanação.

\section{A EFETIVAÇÃO DO DIREITO HUMANO DE ACESSO À JUSTIÇA POR INTERMÉDIO DO PLANO INTERAMERICANO}

Os instrumentos internacionais de proteção dos direitos humanos consagram os parâmetros basilares a serem respeitados pelos Estados, os quais podem ser utilizados perante as instâncias internas e externas. Dentro do campo nacional, os instrumentos internacionais, em conjunto com o Direito pátrio, aprimoram o sistema de proteção dos direitos humanos interno, conferindo um arcabouço protetivo maior aos cidadãos de modo que esses possam reivindicar ainda mais a tutela estatal. Já no âmbito internacional, os referidos instrumentos permitem a invocação da proteção internacional, que responsabiliza o Estado quando os direitos humanos internacionalmente assegurados são violados internamente (PIOVESAN, 2013, p. 207).

Nesse sentido, as violações de direitos humanos inauguram uma nova perspectiva no Direito Internacional: além do seu reconhecimento como sujeito desse ramo do Direito como afirmado anteriormente, elas ensejam a criação de instâncias jurisdicionais para além da órbita estatal, as quais permitam que os indivíduos - agora dotados de direitos e deveres em âmbito internacional possam arguir individualmente diante do Estado violador os danos a si causados pela transgressão da norma jurídica. Afinal, esse papel era exercido apenas pelo Estado, o qual, utilizando da proteção diplomática, poderia arrazoar perante seus pares acerca da ocorrência de violação de uma regra de um nacional seu à Corte Internacional de Justiça - fato esse que naturalmente excluía a possibilidade de o cidadão reivindicar que se arguisse acerca da transgressão de uma norma ante seu próprio Estado em âmbito internacional. 
Logo, o papel de responsabilizar os Estados pela violação de direitos humanos no plano internacional foi assumido pelos Sistemas Regionais de Proteção de Direitos Humanos, os quais se desdobram em três: o Europeu, o Africano e o Interamericano (SHELTON, 2007, p. 1-30). Elaborados com o intuito de auferir maior relevância aos direitos humanos, esses Sistemas são "acionáveis quando o Estado se mostra falho ou omisso na tarefa de implementar direitos e liberdades fundamentais" de qualquer um que esteja sob sua jurisdição, nacionais ou não (PIOVESAN, 1998, p. 51), especificamente, quando não há outra alternativa cabível internamente para fazer valer os direitos transgredidos.

Exatamente por isso, não podem ser esses sistemas compreendidos como uma extensão da jurisdição interna, "não substitu[indo] os tribunais internos e tampouco opera[ando] como tribunais de recursos ou de cassação de decisões de tribunais internos" (TRINDADE, 1997, p. 412). Os Sistemas Regionais são formas de buscar uma reparação em razão da violação de um direito assegurado por seu arcabouço jurídico, mediante a responsabilização de um Estado por intermédio de um Tribunal Internacional, desde que o ente estatal tenha aceitado a sua jurisdição. Por conseguinte, os planos regionais buscam a efetiva instituição dos direitos humanos positivados nos documentos formulados nesses ambientes, exigindo mudanças na conduta de um Estado-parte quanto às suas práticas no tocante a esses direitos, além de compensar as vítimas pela transgressão de seus direitos (HOSTETTLER, 2002, p. 33).

Especificamente no plano interamericano, haja vista a adesão brasileira no ano de 1998 (BRASIL, 2002, preâmbulo), compete à Corte Interamericana de Direitos Humanos, com sede na cidade de São José da Costa Rica, realizar esse controle tendo como base a Convenção Americana de Direitos Humanos e em outros documentos regionais firmados sob os auspícios da Organização dos Estados Americanos (RAMOS, 2012, p. 185).

A responsabilização no ambiente interamericano consubstancia-se especialmente na regra contida no artigo $1^{\circ}$ (1) da referida Convenção, o qual está assim disposto: 
Os Estados-partes nesta Convenção comprometem-se a respeitar os direitos e liberdades nela reconhecidos e a garantir seu livre e pleno exercício a toda pessoa que esteja sujeita à sua jurisdição, sem discriminação alguma, por motivo de raça, cor, sexo, idioma, religião, opiniões políticas ou de qualquer natureza, origem nacional ou social, posição econômica, nascimento ou qualquer outra condição social (ORGANIZAÇÃO DOS ESTADOS AMERICANOS, 1969; BRASIL, 1992).

Isso, pois, tal regra, na jurisprudência da Corte Interamericana, transformou-se em obrigação geral de observância imperativa e extensiva a todos os direitos assegurados pela Convenção (CORTE IDH, 1999). O compromisso assumido pelos Estados que aderiram - ou que venham a aderir - à Convenção e aos demais documentos interamericanos, é no sentido de garantir o cumprimento das obrigações assumidas, não sendo admitidas transações, como a invocação de deficiências administrativas ou da própria legislação interna como alegação para o não cumprimento das regras ali constantes. Nos próprios termos da Corte Interamericana no Caso Niños de La Calle vs. Guatemala, de 1999,

[...] un principio básico del derecho de la responsabilidad internacional del Estado, recogido por el Derecho Internacional de los Derechos Humanos, que todo Estado es internacionalmente responsable por todo y cualquier acto $\mathrm{u}$ omisión de cualesquiera de sus poderes $\mathrm{u}$ órganos en violación de los derechos internacionalmente consagrados. El artículo uno de la Convención Americana es de importancia fundamental en ese sentido (CORTE IDH, 1999).

Assim, os planos regionais permitem a invocação da tutela internacional para responsabilizar o Estado quando os direitos humanos internacionalmente assegurados são violados (PIOVESAN, 2013, p. 207). Ademais, os Sistemas Regionais permitem que se busque uma tutela efetiva para esses direitos, na qual se inclui o acesso à Justiça, o qual, se restasse na mão do Estado sem qualquer tipo de controle (como o ofertado pelo Sistema Interamericano), poderia ser transgredido. 
A propósito, no que respeita à transgressão do direito de acessar a Justiça, essa é uma violação infelizmente tida como comum. Luiz Cesar R. Pereira (2000, p. 147) assevera que são três as causas mais usuais de responsabilidade dos Estados nos foros regionais quanto à transgressão do acesso à Justiça: ( $a$ ) por denegação da justiça; $(b)$ pelo julgamento por tribunal parcial ou de exceção e $(c)$ por decisões contrárias ao Direito. Informações essas que são corroboradas pelos números, os quais mostram "o lugar central que ocupam os problemas relacionados com o funcionamento dos sistemas judiciais nacionais: em torno de $62 \%$ das denúncias se referem a esse tema" somente quando verificadas as petições enviadas ao Sistema Interamericano no ano de 2008, e que se mantêm praticamente idênticas com o passar dos anos (ABRAMOVICH, 2009, p. 16).

Nesse sentido, faz-se importante analisar designadamente o entendimento da Corte Interamericana de Direitos Humanos quanto ao acesso à Justiça, afinal, a realidade do Brasil hoje é paradoxal, haja vista a gama de direitos garantidos constitucionalmente, bem como os direitos assegurados em âmbito internacional e a sua ir(real) garantia, notadamente quanto à prestação jurisdicional efetiva, uma vez que esse país é recorrentemente levado ao Sistema Interamericano pela transgressão dos já comentados artigos $8^{\circ}$ (1) e 25(1) da Convenção Americana (CORTE IDH, 2009; CORTE IDH, 2010). Por isso, na sequência do presente estudo, abordar-se-á o diálogo existente entre a Corte Interamericana e o direito humano de acesso à Justiça, bem como far-se-á uma análise do primeiro caso em que o Brasil foi condenado no Sistema Interamericano, o qual abordou justamente esse tema.

\subsection{A Corte Interamericana de Direitos Humanos e o Direito ao Acesso à Justiça}

Por meio da Convenção Americana de Direitos Humanos foi criado o Sistema Interamericano de Direitos Humanos, que é composto por dois órgãos: (1) a Comissão Interamericana de Direitos Humanos, exercendo 
uma função administrativo-política, a qual investiga as eventuais violações aos direitos humanos, conforme artigo 41 da Convenção Interamericana e (2) a Corte Interamericana dos Direitos Humanos, que julga as violações, tendo uma função jurisdicional, conforme estipula o artigo 52 da referida Convenção (ORGANIZAÇÃO DOS ESTADOS AMERICANOS, 1969; BRASIL, 1992).

Para que um caso chegue à Corte Interamericana, todavia, ele deve ser submetido antes à Comissão Interamericana, de modo que esta tente solucionar a controvérsia preliminarmente, antes da submissão do caso à Corte. Conforme o artigo 44 da Convenção, "qualquer pessoa ou grupo de pessoas, ou entidade não-governamental legalmente reconhecida em um ou mais Estados-membros da Organização, pode apresentar à Comissão petições que contenham queixas de violação" cometidas por um Estado-parte (ORGANIZAÇÃO DOS ESTADOS AMERICANOS, 1969; BRASIL, 1992).

Nessa petição, "o representante deve apontar os fatos que comprovem a violação de direitos humanos denunciada, assinalando, se possível, o nome da vítima e de qualquer autoridade que tenha tido conhecimento da situação” (RAMOS, 2012, p. 209). Ademais, deve cumprir com todos os requisitos do artigo 46, isto é, que tenham se esgotado os recursos internos, que a representação seja apresentada "dentro do prazo de seis meses, a partir da data em que o presumido prejudicado em seus direitos tenha sido notificado da decisão definitiva”, que inexista litispendência ou coisa julgada internacional sobre o tema, e que a petição seja devidamente identificada com o nome, a nacionalidade, a profissão, o domicílio e a assinatura do lesado, representante e/ou entidade (ORGANIZAÇÃO DOS ESTADOS AMERICANOS, 1969, art. 46; BRASIL, 1992).

Admitida a petição, a Comissão solicitará informações ao governo do Estado violador, transcrevendo as partes pertinentes da comunicação, de modo que o ente estatal deverá responder dentro de um prazo razoável 
a ser fixado pela Comissão. Recebidas tais informações ou esgotado tal prazo do Estado, nos termos do artigo 48 da Convenção, a Comissão verifica se subsistem os motivos da petição (podendo, inclusive, realizar visitas in loco ou solicitar informações adicionais), admitindo-a ou arquivando-a (ORGANIZAÇÃO DOS ESTADOS AMERICANOS, 1969, art. 48; BRASIL, 1992). Poderá a Comissão, ainda, declarar a inadmissibilidade da comunicação com base em informação ou prova supervenientes (ORGANIZAÇÃO DOS ESTADOS AMERICANOS, 1969, art. 48; BRASIL, 1992).

Se admitida, a Comissão coloca-se à disposição das partes interessadas, a fim de chegar a uma solução amistosa, redigindo um relatório que será encaminhado ao peticionário e aos Estados-partes, e, posteriormente, transmitido ao Secretário Geral da OEA para a sua publicação. Nos termos do artigo 49 da Convenção, “o referido relatório conterá uma breve exposição dos fatos e da solução alcançada” (ORGANIZAÇÃO DOS ESTADOS AMERICANOS, 1969, art. 49; BRASIL, 1992).

Se não atingida a solução amistosa, contudo, a Comissão "redigirá um relatório no qual exporá os fatos e suas conclusões”, estando ela autorizada a "formular as proposições e recomendações que julgar adequadas" diante do caso, sendo este encaminhado ao Estado violador, ao qual "não será facultado publicá-lo" e que terá o "prazo de três meses contados a partir da remessa” para solucionar o assunto (ORGANIZAÇÃO DOS ESTADOS AMERICANOS, 1969, art. 50; BRASIL, 1992). Então, somente no caso de não ser solucionada a divergência (isto é, se o Estado não acatar as sugestões feitas pela Comissão para remediar o dano ora causado), é que o caso poderá ser submetido à Corte pela Comissão ou pelo Estado interessado (ORGANIZAÇÃO DOS ESTADOS AMERICANOS, 1969, art. 51; BRASIL, 1992). Noutros termos, a Corte só irá apreciar a causa cuja solução tenha sido infrutífera no âmbito da Comissão. 
Importante salientar, porém, que há exceções para os critérios de admissibilidade do caso perante a Comissão, especificamente quanto à desnecessidade de esgotamento dos recursos internos tendo em vista a demora injustificada do Estado em realizar a prestação jurisdicional. Acerca disso, Cançado Trindade (1997, p. 234) elucida que:

Em determinada ocasião, a Comissão indiciou expressamente, como questão de princípio, que os recursos internos a serem esgotados (no âmbito do sistema interamericano) compreendiam apenas os recursos de natureza judicial: a regra de recursos internos não implica que o reclamante tenha que esgotar todos os meios de reparação disponiveis sob a jurisdição do Estado, mas somente aqueles de natureza judicial, e mesmo assim se não ocorrer recusa ou atraso injustificado na administração da justiça (destacou-se).

Esse critério é de suma relevância justamente porque permite que se acione o Sistema Interamericano quando da violação estatal do direito humano de acesso à Justiça. Afinal, se a regra do esgotamento dos mecanismos judiciais internos fosse absoluta, o próprio plano regional estaria privando o indivíduo de realizar o seu direito, fazendo com que fosse perdido o próprio objetivo desse ambiente. Acerca do tema, Ventura Robles (2012, p. 1-2) comenta que

[...] los Estados no deben interponer trabas a las personas que acudan a los jueces o a los tribunales en busca de que sus derechos sean protegidos o determinados. Consecuentemente, cualquier norma o medida estatal, en el orden interno, que dificulte de cualquier manera, uno de ellos, puede ser la imposición de costos, o el acceso de los individuos a los tribunales y que no esté justificado por necesidades razonables de la propia administración de la justicia debe entenderse como contraria a la citada normal convencional.

Assim, designadamente, o artigo 46(2) da Convenção Americana dispõe como pressupostos de admissibilidade a demora injustificada nas decisões e a inexistência do devido processo legal, compondo o que Antô- 
nio Augusto Cançado Trindade (1997, p. 75) afirmou formar "el 'derecho de acceso a la justicia', dotado de contenido propio que expresa el derecho a obtener justicia”. Consideração essa que é importante, vez que demonstra que o acesso à Justiça não é apenas o acesso formal (o poder de petição), mas o real acesso à Justiça significa ter uma decisão revestida de justiça.

Este entendimento exige dos Estados não somente a obrigação de viabilizar o acesso aos recursos disponíveis, como também a obrigação positivada de organizar o aparato judicial institucional para que todos os indivíduos possam ascender à Justiça. Esse é o entendimento da própria Corte Interamericana, exteriorizado no caso Cantos vs. Argentina de 2002, afirmando que os Estados têm o dever de

[...] tomar todas las medidas necesarias para remover los obstáculos que puedan existir para que los individuos puedan disfrutar de los derechos que la Convención reconoce. Por consiguiente, la tolerancia del Estado a circunstancias o condiciones que impidan a los individuos acceder a los recursos internos adecuados para proteger sus derechos, constituye una violación del artículo 1.1 de la Convención (CORTE IDH, 2002).

Nesta mesma linha, a Convenção também prevê que as pessoas que estão sob a jurisdição do Estado devem ter acesso a um recurso eficaz e rápido, ou a qualquer outro recurso diante de juízes ou tribunais competentes que os amparem contra atos que violem os direitos humanos. Ventura Robles (2012, p. 4) também assevera sobre o artigo 25(1) da Convenção (que é justamente sobre direito ao recurso dentro de um prazo razoável), exprimindo que ele "establece la obligación positiva del Estado de conceder a todas las personas bajo su jurisdicción, un recurso judicial efectivo contra actos violatorios de sus derechos fundamentales, derechos fundamentales que pueden estar reconocidos en la Convención Americana o por la propia ley interna”. 
No que diz respeito ao prazo razoável, a Corte já manifestou no caso Salvador Chiriboga vs. Ecuador de 2008 que o

[...] acceso a la justicia tiene relación con la efectividad de los recursos, ya que no es posible afirmar que un recurso existente dentro del ordenamiento jurídico de un Estado, mediante el cual no se resuelve el litigio planteado por una demora injustificada en el procedimiento, pueda ser considerado como un recurso efectivo.

Quer isto dizer que violar o acesso à tutela jurisdicional é também não permitir que o indivíduo tenha uma resposta justa para o seu litígio em um prazo razoável. Quanto mais demorada é a solução do poder Judiciário, menos efetiva ela se torna. Logo, qualquer medida (ou até mesmo norma jurídica interna) que impeça ou dificulte o uso dos recursos pertinentes configura a violação do direito ao acesso à Justiça aos olhos do Sistema Interamericano.

Vale ressaltar que quase na totalidade dos casos brasileiros que chegam até a Corte, o Brasil é condenado por violar o acesso à Justiça. Com base nisso, afirma-se que não há nenhuma segurança no que respeita ao direito da tutela jurisdicional no Estado brasileiro.

O fato, entretanto, de o Brasil ter reconhecido a competência jurisdicional da Corte Interamericana muito recentemente (em 1998 como se desprende do preâmbulo do Decreto n. 4.463/02), bem como seu acesso ser feito somente pelos Estados e pela Comissão Interamericana nos termos dos artigos 48 ao 50 da Convenção Interamericana (diferentemente do Sistema Regional Europeu segundo o qual, desde $1^{\circ}$ de novembro de 1998, o indivíduo recorre diretamente à Corte Europeia de Direitos Humanos sem o uso de instâncias preliminares como ainda ocorre nos modelos africano e interamericano), faz com que o número de casos envolvendo o Brasil perante a Corte seja reduzido. Por outro lado, isto não torna insig- 
nificante a atuação da Corte na proteção dos direitos humanos nos casos relativos ao Brasil, especialmente no que se relaciona à violação do acesso à Justiça.

Assim, uma vez que o foco do presente estudo é a violação do direito humano de acesso à Justiça, o que se verá no caso a seguir apresentado é justamente o retrato dessa conjuntura atual, vez que aborda a primeira situação em que o Brasil foi denunciado ao Sistema Interamericano e levado à Corte pela própria Comissão em razão das abordagens preliminares sob seus auspícios não terem surtido efeito, e justamente por violação do direito em apreço.

\subsection{O Caso Ximenes Lopes vs. Brasil e a Primeira Condenação Brasileira no Nível Interamericano}

A primeira condenação do Estado Brasileiro, por violação de direitos humanos, pela Corte Interamericana, ocorreu no caso Ximenes Lopes vs. Brasil, o qual, coincidentemente, também abordou a questão do acesso à Justiça. Para melhor compreensão do caso, e posteriormente das implicações para o Brasil oriundas da condenação, far-se-á um breve relato dos fatos.

Damião Ximenes Lopes era portador de doença mental e, no mês de outubro do ano de 1999, foi internado na Casa de Repouso Guararapes, situada no município de Sobral, no Ceará, a qual era vinculada com o Sistema Único de Saúde (SUS). Dias após a internação o paciente veio a óbito com graves sinais de tortura, o que reflete as péssimas condições da casa em que estava internado. Apesar dos sinais de maus-tratos, a causa da morte foi atestada como indeterminada.

A família do paciente buscou a jurisdição brasileira, com o objetivo de composição de danos resultantes do tratamento desumano dispensado à Ximenes Lopes, o que acabou por ocasionar a sua morte. A família, con- 
tudo, deparou-se com a desconsideração do Estado do Ceará para com o caso. Diante disto, a irmã da vítima, Irene Ximenes, obrigou-se a denunciar o caso à Comissão Interamericana de Direitos Humanos, ressaltando a violação de diversos direitos elencados no Pacto de San José da Costa Rica, como o direito à vida, à integridade pessoal, garantias judiciais, bem como proteção judicial (BORGES, 2009, p. 10).

Depois de notificar o Estado brasileiro para se manifestar acerca das acusações sofridas, sem obtenção de nenhuma resposta por parte do Brasil e passado o procedimento de praxe (explicitado no ponto anterior), em 2002, a Comissão se reconheceu competente para análise do caso. Em outubro do ano seguinte a Comissão concluiu pela violação de diversos artigos da Convenção Interamericana de Direitos Humanos, remetendo ao Brasil um relatório com recomendações para investigar de maneira adequada o caso, além de indenizar a família da vítima, com o intuito de evitar futuras situações semelhantes.

Passado um ano, nenhuma recomendação havia sido cumprida. A Comissão, então, submeteu o caso à Corte Interamericana de Direitos Humanos, requerendo que decidisse se o Brasil era responsável pela violação aos artigos $4^{\circ}, 5^{\circ}$ e 25 , além do descumprimento da obrigação disposta no artigo $1^{\circ}$ (1) da Convenção. Em suma, a Comissão tinha como finalidade reconhecer a responsabilidade do Estado pela morte do senhor Damião Ximenes Lopes, assim como pelo descaso nas investigações e no Sistema Judiciário para a punição dos responsáveis.

No andar do processo, o Brasil veio a reconhecer sua responsabilidade no que tange ao direito à vida e à integridade pessoal. Por fim, em sentença proferida em julho de 2006, a Corte reconheceu a responsabilidade parcial do Estado brasileiro por violação, em relação à vítima, aos $\operatorname{artigos} 1^{\circ}$ (1) (obrigação de respeitar os direitos), $4^{\circ}$ (1) (direito à vida) e $5^{\circ}$ (1) (direito à integridade física), e em relação a sua família os artigos $8.1^{\circ}$ (o direito à jurisdição, acesso à Justiça) e 25 (1) (prazo razoável na 
postulação em juízo), do Pacto de San José da Costa Rica. A condenação somou valor equivalente a US\$ $178.350,00$, dos quais US\$ $53.350,00$ correspondiam a dano material e US\$125.000,00 a danos morais (CORTE IDH, 2006).

Vale ressaltar que, na data em que a Corte reconheceu responsabilidade do Brasil, ainda não havia sido proferida sentença no processo penal iniciado mais de seis anos antes, em julho de 2000, quando foi oferecida denúncia pelo Ministério Público. O mesmo descaso ocorreu na ação civil de reparação de danos (BORGES, 2009, p. 66), restando evidente a merecida condenação pelo descaso do Estado brasileiro diante do ocorrido, não oferecendo uma tutela jurisdicional digna aos seus cidadãos.

Vale aqui ressaltar que a Corte no caso Ivcher Bronstein vs. Perú, de 2001, definiu a abrangência da aplicabilidade do citado artigo da Convenção ao postular que, apesar do dispositivo titular-se "garantias judiciais" considera-se que

[...] su aplicación no se limita a los recursos judiciales en sentido estricito, sino al conjunto de requisitos que deben observarse en las instancias procesuales, a efecto de que las personas puedan defenderse adecuadamente ante cualquier acto emanado del Estado que puede afectar sus derechos (CORTE IDH, 2001).

Nota-se que o fato não é apenas uma violação internacional, senão também o próprio Direito interno brasileiro, isto porque no ordenamento brasileiro o teor dos dispositivos anteriormente citados encontra-se, em síntese, nos incisos XXXV e LIV do artigo $5^{\circ}$ da Constituição de 1988. Tais artigos trazem o Princípio da Inafastabilidade da Jurisdição e o Princípio do Devido Processo Legal como sendo garantias fundamentais indispensáveis ao Brasil. Para André Ramos Tavares (2010, p. 666), o acesso à Justiça preconizado no inciso XXXV do artigo $5^{\circ}$ da Constituição do Brasil é 
[...] um dos pilares sobre o qual se ergue o Estado de Direito, pois de nada adiantariam leis regularmente votadas pelos representantes populares se, em sua aplicação, fossem elas desrespeitadas, sem que qualquer órgão estivesse legitimado a exercer o controle de sua observância. O próprio enunciado da legitimidade, portanto, como já observado, requer que haja a apreciação de lesão ou ameaça a direito pelo órgão competente.

No caso em comento, evidencia-se o total desrespeito ao direito de acesso à Justiça. Conforme relatado, a família de Damião Ximenes Lopes buscou, na jurisdição brasileira, uma reparação perante o Estado, entretanto houve uma total desconsideração das autoridades estatais para com o ocorrido, durante todo o caso, mas principalmente na fase processual.

A atuação ineficaz do Estado no caso acarretou dificuldades e impedimentos no acesso à jurisdição. Tal fato resulta em sério problema recorrente no Brasil: a impunidade. Ademais, quando foi possível entrar com a ação penal para punição dos responsáveis pelo óbito, enfrentou-se o crônico problema do Judiciário brasileiro, a morosidade processual.

Desse modo, entende-se à luz dos conceitos dos direitos humanos e constitucionais, principalmente no que tange ao acesso à Justiça e ao princípio do devido processo legal, que a violação aos direitos humanos no caso em tela ocorreu em dois momentos distintos: um quanto à maneira como foi tratado o paciente deficiente mental, o que resultou na sua morte, e outro quanto ao caminho dificultoso para responsabilização dos culpados pelo fato, ou seja, o acesso ao poder Judiciário (ROSATO; CORREIA, 2011, p. 103).

Em razão da negligência do Judiciário brasileiro, a família da vítima teve de buscar acesso à jurisdição internacional, o que não diminui a soberania estatal, mas acaba por deixar maculada a imagem do Judiciário brasileiro perante a comunidade internacional. Acerca desta matéria, Maria Carolina Florentino Lascala (2010, p. 32) assim se expressa: 
Tendo em conta que o tribunal internacional profere sentenças por força de um tratado assinado e ratificado pelo Estado-parte, em que este transferiu parcela do seu poder de imperium quando se sujeitou à jurisdição daquele, não há que se falar em desrespeito à autonomia e à exclusividade da jurisdição do poder Judiciário brasileiro ao acatar tal decisão.

Isto é, não há que se falar em não aceitação das medidas impostas pela Corte do Brasil, vez que este ratificou a Convenção Americana de Direitos Humanos e aceitou a sua jurisdição. A Corte afirmou que a falta de investigação e de garantias judiciais no tratamento do caso por parte do Estado brasileiro, assim como a gravidade do evento, tanto pela vulnerabilidade da vítima - que possuía incapacidade mental - quanto em virtude da obrigação do Brasil de conferir proteção para os usuários do SUS (COELHO, 2008, p. 122).

A sentença proferida pela Corte Interamericana de Direitos Humanos reconheceu a responsabilidade internacional do Brasil por violar o acesso à justiça, por não ter proporcionado à família de Damião Lopes Ximenes um recurso efetivo para garantir o acesso à Justiça, a determinação dos fatos, a investigação, a identificação, o processo e a punição dos responsáveis, assim como os outros dispositivos da Convenção. Além disso, a Corte também considerou a demora processual, pois não houve sequer sentença de primeiro grau após seis anos do início da ação penal, como uma violação do acesso à Justiça e do direito à duração razoável do processo.

A decisão da Corte foi unânime e afirmou que o Estado tem o dever de garantir o efetivo acesso à Justiça, bem como a celeridade da Justiça para investigar e sancionar os responsáveis pela tortura e morte de Damião Ximenes (CORTE IDH, 2006). O Brasil ficou, de igual modo, condenado a continuar desenvolvendo um programa de formação e capacitação para os profissionais vinculados ao atendimento de saúde mental; 
pagar indenização como medida de reparação à família da vítima e publicar a sentença no Diário Oficial ou em jornal de circulação nacional. Ao verificar a condenação, percebe-se a preocupação da Corte em não somente punir o culpado e ao pagamento de indenização pecuniária, mas também de evitar que tal direito seja novamente violado, bem como divulgar o caso para que se torne público, inibindo, assim, os Estados, de cometerem futuras violações.

Depois de proferida a decisão, o Brasil cumpriu os pontos referentes à publicação de parte da sentença e ao pagamento indenização. Hoje há, nesse sentido, um cumprimento parcial da sentença pelo Brasil, o que faz com que o caso ainda esteja sujeito à supervisão da Corte, nos termos do artigo 65 da Convenção (ORGANIZAÇÃO DOS ESTADOS AMERICANOS, 1969; BRASIL, 1992). Há, ainda, uma Resolução de 17 de maio de 2010, na qual a Corte determinou não fechar o procedimento de supervisão de cumprimento de sentença, tendo em vista que o Brasil ainda não cumpriu os pontos que se referem ao desenvolvimento de políticas públicas na área de saúde mental segundo os princípios internacionais acerca da matéria e à conclusão do processo em prazo razoável, bem como efetivo acesso à Justiça.

Importa esclarecer que a Corte afirmou, em várias oportunidades, que a garantia do recurso efetivo e do acesso à Justiça constitui um dos pilares basilares, não somente da Convenção, mas também do Estado Democrático de Direito. Para que o Estado cumpra o postulado nos artigos da Convenção não se faz suficiente que existam recursos formalmente, mas que estes permitam aos indivíduos a real possibilidade de acessar a Justiça ou interpor um recurso célere e com eficácia, como restou esclarecido a partir do já citado caso Ivcher Bronstein vs. Perú de 2001 (CORTE IDH, 2001). 
A leitura de julgados da Corte revela, na prática, como a proteção internacional dos direitos humanos faz-se importante e precisa estar presente no Brasil e também nos demais países americanos. A atuação da Corte permite a introdução de mudanças no âmbito interno que convergem para exterminar os fatores de violação e, por consequência, fortalecem a proteção dos direitos humanos. A Corte promoveu o acesso à Justiça em diversas oportunidades nas quais a Justiça interna demonstrou ser insuficiente para a efetiva proteção de tal direito humano.

\section{CONSIDERAÇÕES FINAIS}

Visto que o acesso à Justiça sofreu grande evolução no decorrer dos tempos, sendo considerado atualmente um direito que possibilita a efetivação dos demais, haja vista o fato de ele permitir que os indivíduos busquem o remédio judicial cabível para efetivar e reconhecer outros direitos, sendo, portanto, essencial para a garantia da dignidade da pessoa humana - elemento basilar dos direitos humanos. Afinal, o alcance à Justiça não se resume somente à elaboração de petição ou na existência de leis, abrangendo também a garantia dos direitos econômicos, sociais e culturais dos cidadãos, os quais podem ser realizados por meio do poder Judiciário, sendo um mecanismo importantíssimo para a atribuição da igualdade e da diminuição das disparidades socioeconômicas nas sociedades. Por isso, o acesso à Justiça é reconhecido universalmente como um direito humano, devendo ser garantido pelos Estados a todos aqueles que estão nas suas jurisdições, nacionais ou não.

Destarte, o acesso à Justiça foi insculpido no Brasil - e em outros Estados - em diversos diplomas legais domésticos ao longo dos anos. Destaque, todavia, dá-se à Constituição de 1988, também chamada de Constituição Cidadã, a qual alçou o acesso à Justiça ao patamar de direito fun- 
damental, conferindo às pessoas o direito de ação, bem como a proteção à lesão ou ameaça de direito, sem olvidar de um processo com duração razoável.

Não só prescrito por diplomas internos, o acesso à Justiça também está disposto em diversos tratados internacionais, como na Declaração Universal dos Direitos Humanos e na Convenção Americana de Direitos Humanos. Esses documentos normativos evidenciam o caráter internacional e firmam o elo existente entre o direito fundamental e o direito humano, no que diz respeito ao acesso à Justiça, resguardando-o tanto no ordenamento interno quanto no internacional, promovendo, com isso, uma sólida promoção acerca da proteção e da necessidade de realização dos direitos humanos por parte dos Estados.

Não só, portanto, pela previsão constitucional do direito ao acesso à Justiça, esse direito deve ser igualmente observado e garantido pelos Estados - como o Brasil - em razão do princípio da dignidade humana (quanto à Declaração Universal dos Direitos Humanos - uma regra costumeira em Direito Internacional) e do pacta sunt servanda (em razão da ratificação da Convenção Americana de Direitos Humanos). Quer isso referir que não há que se falar em descumprimento dessas medidas por parte do ente estatal, nem mesmo quando esse invoca legislação ou barreiras internas para justificar a sua decisão de transgredir as normas internacionais.

Logo, quando não é permitido o acesso dos cidadãos ao poder Judiciário; quando o devido processo legal é descumprido; ou quando há uma demora injustificada na duração do processo, tem-se que o Estado está em desacordo tanto com as suas normativas internas quanto com as internacionais. Atos esses que violam diretamente o direito humano de acessar a Justiça, posto que tais condutas privam o indivíduo de fazer valer os seus direitos, isto é, de buscar a "justiça”, como se defendeu na primeira parte deste trabalho. 
E nesses casos, o ente estatal está sujeito a ser responsabilizado internacionalmente, haja vista a conduta (por vezes ativa, por vezes omissiva) do seu poder Judiciário gerar um dano ao indivíduo, violando diretamente a sua dignidade humana. À vista disto, torna-se claro o papel dos Tribunais Internacionais na promoção do acesso à Justiça e a sua importância como operador de mudanças que fazem possível a solidificação das garantias de proteção dos direitos humanos no plano interno dos Estados. Isso pois eles garantem ao indivíduo um mecanismo para que este reivindique a garantia do seu direito perante o Estado, o qual pode ser até mesmo aquele que lhe confere a sua nacionalidade, não sendo mais esse fato um empecilho à preservação dos direitos da pessoa no plano internacional.

Ao alçar a pessoa como sujeito de Direito Internacional, por conseguinte, faz com que ela possa advogar por si mesma no plano internacional, de modo que devem ser ofertados mecanismos pelos quais ela poderá fazer valer os seus direitos já internacionalmente positivados. Assim, trabalhou-se na segunda parte do presente texto com o Sistema Interamericano de Proteção de Direitos Humanos - um dos modelos de proteção regional de direitos humanos existentes ao redor do globo que oferece ao indivíduo certa capacidade para atuar e buscar que os Estados adéquem às suas condutas as obrigações por estes assumidas.

Afinal, os tribunais internacionais, sobretudo no âmbito regional, têm o poder para auxiliar na efetivação dos direitos humanos, possibilitando mudanças na realidade jurídica interna a partir de suas decisões, ampliando e consolidando, com isso, a proteção dos direitos humanos. Até mesmo porque, de nada adiantaria ter-se o direito positivado se não fosse possível utilizar-se dele.

Especificamente quanto ao Brasil, tem-se que o país não parece cumprir com as suas obrigações internacionais de forma efetiva, especialmente quanto ao direito humano de acesso à Justiça, posto que todas as vezes que o Estado brasileiro foi acionado no plano interamericano, 
falou-se na denegação do referido direito. Nesse sentido, nota-se a importância que o plano internacional, notadamente o ambiente interamericano, possui para efetivar tal direito por meio da responsabilização do Estado, obviamente com a devida anuência do Brasil, o qual aceitara a jurisdição da Corte em 1998, permitindo que ela exercesse sua jurisdição perante o Estado brasileiro.

Exemplo disso foi o caso do Damião Ximenes Lopes, o qual não foi apenas a primeira condenação do Estado brasileiro perante a Corte Interamericana, mas também foi a primeira responsabilização internacional brasileira pela violação dos artigos $8^{\circ}$ (1) e 25(1) da Convenção Americana de Direitos Humanos de 1969, ratificada pelo Brasil em 1992 - caso esse que denota as limitações do poder Judiciário pátrio e as dificuldades que o Brasil tem em garantir o acesso à Justiça de maneira eficaz a todos os seus cidadãos.

O Brasil, um país que se pretende democrático, portanto transparente e garantidor de direitos, que desponta no cenário internacional como grande potência em desenvolvimento, não pode lidar com os acontecimentos relativos aos direitos humanos de maneira ineficiente como vem fazendo. Há que se efetivar o direito humano de acesso à Justiça. Nesse escopo, talvez se precise de mais Irenes Ximenes Lopes que levem os casos ao Sistema Interamericano, para que o Brasil, sofrendo das implicações cabíveis diante da responsabilização internacional, tome medidas apropriadas para fazer com que as violações sejam inibidas, desenvolvendo, dessa forma, uma cultura mais aberta ao respeito do próprio Direito Internacional, carregando consigo o acesso à Justiça.

Até mesmo porque a promoção de uma sólida cultura de proteção e realização dos direitos humanos no plano interno terminaria por gerar uma conscientização e mobilização da sociedade civil e dos agentes do Estado para com a prevalência dos direitos humanos. Nesse cenário, que é favorável ao avanço do Direito Internacional dos direitos humanos no 
plano interno, a postura omissiva seria aos poucos substituída por uma postura proativa e equânime, comprometida com a redução das desigualdades, e, portanto, preocupada em garantir o acesso à Justiça.

\section{REFERÊNCIAS}

ABRAMOVICH, Victor. Das violações em massa aos padrões estruturais: novos enfoques e clássicas tensões no Sistema Interamericano de Direitos Humanos. Revista Sur 21, São Paulo, v. 6, n. 11, p. 1-20, jan. 2009.

ALVES, Cléber Francisco. Igualdade no Acesso à Justiça - assistência jurídica numa perspectiva comparada: Brasil, França e Suécia. Revista da Faculdade de Direito da Universidade Católica de Petrópolis, Rio de Janeiro: Lúmen Juris, v. $5,2003$.

ANDREW-GUZMAN, Frederico. 30 años de La Convención Americana sobre Derechos Humanos: Todavía hay mucho camino por recorrer. In: El Sistema Interamericano de Protección de los Derechos Humanos en el Umbral del Siglo XXI. San José: Corte Interamericana de Derechos Humanos, 2003. Tomo I.

ANNONI, Danielle. Acesso à Justiça e Direitos Humanos: a EC 45/2004 e a garantia à razoável duração do processo. In: CONGRESSO NACIONAL DO CONPEDI, 16., 2008, Belo Horizonte. Anais..., Belo Horizonte, 2008. p. 6.6826.693 .

. Direitos humanos e acesso à justiça no Direito Internacional. Curitiba: Juruá, 2009.

AVILA, Leandro C. Evolução dinâmica do acesso à justiça: o paradigma da eficiência e os procedimentos eletrônicos. In: KNOERR, Fernando Gustavo; NEVES, Rubia Carneiro; CRUZ, Luana Pedrosa de F. (Org.). Justiça e o paradigma da eficiência na contemporaneidade. São Paulo: Funjab, 2014. p. 315-332. V. 1.

BEZERRA, Paulo Cesar Santos. Acesso à justiça: um problema ético-social no plano da realização do direito. Rio de Janeiro: Renovar, 2008. 
BITTAR, Eduardo Carlos Bianca. Curso de Filosofia do Direito. São Paulo: Atlas, 2001.

BORGES, Nadine. Damião Ximenes: primeira condenação do Brasil na Corte Interamericana de Direitos Humanos. Rio de Janeiro: Renovar, 2009.

BRASIL. Constituição Federal.1988.

. Lei Federal n. 4.717. 1965.

. Lei Federal n. 7.244. 1984.

. Decreto n. 89. 1998.

. Decreto n. 678. 1992.

. Decreto n. 4.463. 2002.

. Emenda Constitucional n. 45. 2004.

BURRIEZA, Ángela Figueruelo. El Derecho a la Tutela Judicial Efectiva. Madrid: Tecnos, 1990.

CAPPELLETTI, Mauro; GARTH, Bryan. Acesso à justiça. Porto Alegre: Sergio Antônio Fabris, 1988.

CARDOSO, Tatiana de Almeida Freitas R. A responsabilidade internacional dos Estados como meio de efetivação dos Direitos Humanos. In: MENEZES, Wagner (Org.). Estudos de Direito Internacional. Curitiba: Juruá, 2010. p. 337350. Vol. XX.

. Direitos humanos: da sua evolução à sua (in) efetividade. Revista Videre, Curitiba, v. 4, n. 8, p. 30-40, 2014.

CARLIN, Volnei Ivo. In: ANNONI, Danielle. Direitos humanos e acesso à justiça no Direito Internacional. Curitiba: Juruá, 2009.

CICHOKI NETO, José. Limitações ao acesso à justiça. Curitiba: Juruá, 2000. CINTRA, Antonio Carlos de Araújo; GRINOVER, Ada Pelegrini; DINAMARCO, Cândido Rangel. Teoria geral do processo. São Paulo: Saraiva, 2014. COELHO, Rodrigo Meirelles Gaspar. Proteção internacional dos direitos humanos: a Corte Interamericana e a implementação de suas sentenças no Brasil. Curitiba: Juruá, 2008. 
COMPARATO, Fábio Konder. Direito público: estudos e pareceres. São Paulo: Saraiva, 1996.

CORTE IDH. Caso Niños de La Calle vs. Guatemala. Sentença de mérito julgada em 19 de novembro de 1999. Disponível em: <http://www.corteidh.or.cr/ ninosdelacalle>. Acesso em: 28 maio 2015.

Garibaldi vs. Brasil. Sentença de 23 de setembro de 2009. Série C, n.203. Disponível em: <http://www.sdh.gov.br/assuntos/atuacao-internacional/sentencas-da-corte-interamericana/sentenca-garibaldi $>$. Acesso em: 6 jul. 2016.

. Caso Gomes Lund e outros (Guerrilha do Araguaia) vs. Brasil. Sentença de 24 de novembro de 2010. Série C, N. 219. Disponível em: <http://www.sdh. gov.br/assuntos/atuacao-internacional/sentencas-da-corte-interamericana/ sentenca-araguaia-24.11.10->. Acesso em: 6 jul. 2016.

Caso Ivcher Bronstein vs. Perú. Fondo. Reparaciones y Costas, Sentencia de 6 de febrero de 2001. Serie C, n.74. Disponível em: <http://www. corteidh.or.cr/ivcherbronsteinvsperu>. Acesso em: 29 maio 2015.

. Caso Cantos vs. Argentina. Fondo, Reparaciones y Costas. Sentencia de 28 de noviembre de 2002. Serie C, n. 97. Disponível em: <http://www. corteidh.or.cr/cantosvsargentina>. Acesso em: 29 maio 2015.

. Caso Ximenes Lopes vs. Brasil. Sentença de 4 de julho de 2006, Série C, N. 149. Disponível em: <http://www.corteidh.or.cr/casoximeneslopesvsbrasil >. Acesso em: 29 maio 2015

. Caso Salvador Chiriboga vs. Ecuador. Excepción Preliminar y Fondo. Sentencia de 6 de mayo de 2008. Série C, n.179. Disponível em: <http://www. corteidh.or.cr/salvadorchiribogavsecuador>. Acesso em: 29 maio 2015.

DIAS, Ronaldo Brêtas de C. Responsabilidade do Estado pela função jurisdicional. Belo Horizonte: Del Rey, 2004.

DINAMARCO, Candido Rangel. A instrumentalidade do processo. 15.ed. São Paulo: Malheiros, 2013. 
DIREITO, Carlos Alberto Menezes. A prestação jurisdicional e a efetividade dos direitos declarados. Revista da EMERJ, Rio de Janeiro, v. 1, n. 1, p. 141146, 1998.

DUARTE NETO, Bento Herculano. Princípios de Direito Processual Civil. In: DUARTE NETO, Bento H.; LUCON, Paulo Henrique; TEIXEIRA, Sergio Torres. Teoria Geral do Processo. 5. ed. Curitiba: Iesde, 2012.

ESPANHA. Constituição Federal, 1978.

FERREIRA, Patrícia Galvão. Responsabilidade Internacional do Estado. In: LIMA JUNIOR, Jayme B. (Org.) Direitos humanos internacionais: avanços e desafios no início do século XXI. Recife: Gajop, 2001.

FRANCO, Maria Eugênia S. Os meios de comunicação em massa e o sistema jurídico: a mídia como um instrumento de controle social. Revista da Faculdade de Direito-UFU. Uberlândia, v. 42, n. 2, p. 268-291, 2014.

GRINOVER, Ada Pellegrini. A inafastabilidade do controle jurisdicional e uma nova modalidade de autotutela. In: AMARAL: Antônio Carlos R.; ROSAS, Roberto; VELLOSO, Carlos Mário da S. (Coord.). Princípios constitucionais fundamentais. São Paulo: Lex Ed., 2005.

GRINOVER, Ada Pellegrini; DINAMARCO, Candido Rangel. Teoria geral do processo. São Paulo: Saraiva, 2014.

HOBBES, Thomas. Leviatã. Trad. João Paulo Monteiro e Maria Beatriz N. da Silva. São Paulo: Abril, 1997 (Coleção os Pensadores).

HORTA, Jesus. O Código de Direito Canônico e o Ecumenismo. São Paulo: Loyola, 2003.

INTERNATIONAL LAW COMMISSION (ILC). Draft Articles on State Responsibility. 2001. Disponível em: <http://legal.un.org/ilc/texts/instruments/ english/draft_articles/9_6_2001.pdf>. Acesso em: 5 jun. 2016.

HOSTETTLER, Peter. Human Rights and the "War" against International Terrorism. Sanremo: International Institute of Humanitarian Law, 2002.

JAKOBSEN, Uffe. O conceito de cidadania. In: FERES JUNIOR, João; JASMIN, Marcelo. História dos conceitos: diálogos transatlânticos. Rio de Janeiro: PUC-Rio; Loyola, 2007. 
KELSEN, Hans. Teoria Pura do Direito. 4. ed. São Paulo: Martins Fontes, 2000. LASCALA, Maria Carolina F. A execução das sentenças da Corte Interamericana de Direitos Humanos. In: Anais das jornadas para jóvenes investigadores en derecho y ciencias sociales, n. 2., Buenos Aires, Argentina, 2010.

LIMA FILHO, Francisco das Chagas. Acesso à justiça e os mecanismos extrajudiciais de solução de conflitos. Porto Alegre: Sergio Antonio Fabris, 2003.

MARTINS, Alexandre Marques. Os valores em Miguel Reale. Revista de Informação Legislativa, Brasília, a. 45, n. 180, p. 263-277, out./dez. 2008.

MAZZUOLI, Valério de Oliveira. Teoria geral do controle de convencionalidade no direito brasileiro. Revista Direito e Justiça - Reflexões Sociojurídicas, Santo Ângelo, a. IX, n. 12, p. 235-276, mar. 2009.

MELHADO, Reginaldo. Acesso à Justiça como Direito Humano. Revista TRT, Curitiba, v. 27, n. 1, 2002.

MELLO, Marcos Bernardes de. Teoria do Fato jurídico: plano da eficácia. São Paulo: Saraiva, 2003. V. I.

MERON, Theodor. On a Hierarchy of International Human Rights. American Journal of International Law, Washington D.C., vol. 80, p. 1-23, 1986.

MORAIS, Humberto Pena de; SILVA, José Fontanelle da. Assistência judiciária: sua gênese, sua história e função protetiva do Estado. 2. ed. Rio de Janeiro, 1984.

OLIVEIRA, Simone dos Santos. Defensoria pública brasileira: sua história. Revista de Direito Público. Londrina, v. 2, n. 2, p. 59-74, maio/ago. 2007.

ORGANIZAÇÃO DAS NAÇÕES UNIDAS (ONU). Carta das Nações Unidas. 1945.

. Resolução 217(A) - Assembleia Geral. 1948.

. Convenção de Viena sobre o Direito dos Tratados. 1969.

ORGANIZAÇÃO DOS ESTADOS AMERICANOS (OEA). Convenção Americana de Direitos Humanos. 1969. 
PEREIRA, Luis Cezar Ramos. Ensaio sobre a responsabilidade internacional do Estado e suas conseqüências no direito internacional: a saga da responsabilidade internacional do Estado. São Paulo: Ltr, 2000.

PIOVESAN, Flávia. Temas de direitos humanos. São Paulo: Max Limonad, 1998. . Direitos humanos e o Direito Constitucional Internacional. São Paulo: Saraiva, 2013.

PINHEIRO, Aline. Corte europeia tenta acabar com lentidão judicial. Revista Consultor Jurídico, publicada em $1^{\circ}$ dez. 2013. Disponível em: <http://www. conjur.com.br/2013-dez-01/corte-europeia-tenta-obrigar-paises-resolver-lentidao-judicial>. Acesso em: 28 maio 2015.

REALE, Miguel. Filosofia do Direito. 13. ed. São Paulo: Saraiva, 1990. . Invariantes axiológicas. Estudos Avançados, São Paulo, v. 5, n. 13, p. 131-144, 1991.

RAMOS, André de Carvalho. Processo internacional de direitos humanos: análise dos sistemas de apuração de violações de direitos humanos e a implementação das decisões no Brasil. 2. ed. Rio de Janeiro: Renovar, 2012.

Responsabilidade internacional por violação de direitos humanos. Rio de Janeiro: Renovar, 2004.

ROCHA, João Carlos de C. Ação civil pública e acesso à justiça. In: ROCHA, João Carlos de C.; HENRIQUES FILHO, Tarcísio H. (Org.). Ação civil pública: 20 anos da Lei n. 7.347/85. Belo Horizonte: Del Rey, 2005.

ROSATO, Cássia Maria; CORREIA, Ludmila Cerqueira. Caso Damião Ximenes Lopes: Mudanças e desafios após a primeira condenação do Brasil pela Corte Interamericana de Direitos Humanos. Sur - Revista Internacional de Direitos Humanos, São Paulo, v. 8, n. 15, p. 93-113, dez. 2011.

ROSSI, Mariane. Mulher espancada após boatos em rede social morre em Guarujá, SP. Jornal G1. Publicada em 5 maio 2014. Disponível em: <http:// g1.globo.com/sp/santos-regiao/noticia/2014/05/mulher-espancada-apos-boatos-em-rede-social-morre-em-guaruja-sp.html>. Acesso em: 28 maio 2015. SERRANO JÚNIOR, Odoné. Responsabilidade Civil do Estado por Atos Judiciais. Curitiba: Juruá, 1995. 
SHELTON, Dinah. An Introduction to the History of International Human Rights Law. George Washington University Legal Studies Research Paper, n. 346. aug., 2007.

TAVARES, André Ramos. Curso de Direito Constitucional. 8. ed. São Paulo: Saraiva, 2010.

TEIXEIRA, Sergio Torres. Jurisdição. In: DUARTE NETO, Bento H.; LUCON, Paulo Henrique; TEIXEIRA, Sergio Torres. Teoria geral do processo. 5. ed. Curitiba: Iesde, 2012.

THEODORO JUNIOR, Humberto. Curso de Direito Processual Civil. Rio de Janeiro: Forense, 1993.

TRINDADE, Antônio Augusto Cançado. A proteção internacional dos direitos humanos: fundamentos jurídicos e instrumentos básicos. São Paulo: Saraiva, 1991.

. O esgotamento dos recursos internos. 2. ed. Brasília: UNB, 1997. . Tratado de Direito Internacional dos Direitos Humanos. Porto Alegre: Sergio Antônio Fabris, 1997.

TUCCI, José Rogério Cruz e. Tempo e Processo. São Paulo: Editora Revista dos Tribunais, 1997.

VENTURA ROBLES, Manuel. La jurisprudencia de la Corte Interamericana de Derechos Humanos en Materia de Acceso a la Justicia e Impunidad. 2012. Disponível em: <http://www.corteidh.or.cr/tablas/r24428.pdf>. Acesso em: 29 maio 2015.

WATANABE, Kazuo. Acesso à justiça e sociedade moderna. In: GRINOVER, Ada. Pelegrini (Org.). Participação e processo. São Paulo: Revista dos Tribunais, 2009. 